Dmitrij Dobrovol'skij, Ludmila Pöppel

\title{
Corpus perspectives on Russian discursive units: semantics, pragmatics, and contrastive analysis
}

The present study analyzes a group of Russian discursive units with focus-sensitive semantics such as imenno (just/precisely), kak raz (just/precisely), to-to $i$ ono (that's just it/the point/problem), to-to $i$ est' (that's just it/the point/problem) and to-to $i$ delo (that's just it/the point/problem). They are important elements of communication but have not yet been adequately described. Some of the analyzed lexical units - for example, imenno and kak raz or to-to i ono; to-to $i$ est' and to-to $i$ delo - are near synonyms. Others, such as kak raz and to-to $i$ ono, are not near synonyms, but they nevertheless belong to the semantic class of focus-sensitive elements. Thus they can all be put into a single group according to the principle of family resemblance. The material itself suggests the logic of the analysis - on the basis of pairs or groups of the semantically closest near synonyms: 1) imenno vs. kak raz; 2) imenno vs. to-to $i$ ono; 3 ) to-to $i$ ono vs. to-to $i$ est' vs. to-to $i$ delo.

Near-synonyms within these groups can be distinguished from each other on the basis of semantics, pragmatics, and usage preferences. Identifying differences of various types requires a good corpus with numerous examples, for they can be present simultaneously on several levels: semantic and pragmatic, pragmatic and usual, etc. Often, although not always, pragmatic and/or usual differences are semantically motivated. Syntactic distinctions among near-synonyms, including those in certain syntactic patterns, are also generally motivated by differences in their semantics. In a number of cases the problem is solved through the use of translational equivalents; that is, not on the level of individual lexical units (words and phrasemes) but on that of the entire utterance. Using relevant lexicographic information, text corpora, including parallel corpora, and works of fiction, we shall:

a) clarify semantic and pragmatic properties as well as usage peculiarities of the focus sensitive discursive units imenno, kak raz, to-to i ono, to-to i est' and to-to i delo;

b) analyze their systemic and translational equivalents in English and Swedish.

Keywords: discursive units, focus sensitive items, synonymy, cross-linguistic equivalence, systemic equivalents, translational equivalents. 


\section{Research goals and data}

There is a group of discursive units in Russian ${ }^{1}$ which have a certain semantic resemblance and common pragmatic features. All of these units are focus-sensitive.

The group of units considered in the present study includes the particles and constructions imenno (just/precisely), kak raz (just/precisely), to-to i ono (that's just it/the point/problem), to-to i est' (that's just it/the point/problem) and to-to i delo (that's just it/the point/problem). Some of them are traditionally described as synonyms, for example, imenno and kak raz in MAS (1985-1988), BTS (2002); to-to i ono and to-to i est' in Molotkov (1967). Intuitively one senses that despite the similarity in meaning of those described as synonyms, they are not interchangeable in all contexts because each of them has individual characteristics.

The pragmatic function of the group of units under consideration depends on the dialogic situation and can consist in the expression of agreement, disagreement, doubt, etc. In certain contexts some of these units are interchangeable. Elsewhere, however, they cannot be easily substituted for each other, since the semantic structure of each of the units contains features that the semantics of the others lacks, and there are also other reasons of a pragmatic and stylistic nature. Obviously, in contexts in which individual semantic features are being profiled, substituting a unit for a near-synonym is impossible.

The pragmatic limitations derive from the specific functional preferences of each of these units. For some of them expressing agreement is more typical, whereas for others it is disagreement. Certain functional peculiarities and distinguishing semantic features have already been described in the literature, especially with reference to imenno, kak raz and to-to i ono on the basis of Russian materials (Dobrovol'skij and Levontina 2012, 2014, Levontina 2004, Paillard 1998a, 1998b) and eben, gerade, ausgerechnet on the basis of a Russian-German and German-Russian parallel corpus (Dobrovol'skij and Šarandin 2013). Using corpus data, including materials of parallel corpora, the present study aims to identify and describe the distinguishing characteristics of the discursive units imenno, kak raz, to-to i ono, to-to i est' and to-to i delo and their translational equivalents in English and Swedish.

Our working hypotheses are as follows:

\footnotetext{
${ }^{1}$ For descriptions of Russian discursive words see especially Baranov et al. (1993), Kiseleva and Paillard (1998, 2003), Kobozeva and Zakharov (2004), Kobozeva (2006, 2007), Paukkeri (2006), Šaronov (2009) which are specifically devoted to this layer of the lexicon. Such lexical units in other languages are studied, for example, in Fischer (2000), Sorjonen (2001), Travis (2005), Romero-Trillo (2009).
} 
a) differences among near-synonyms are determined not only by semantics, but can be motivated by pragmatics and usage as well;

b) syntactic differences between the synonyms considered here are motivated by semantic differences;

c) because different languages lack semantic equivalents, they solve the problem on the level of the utterance, where they encounter not systemic equivalents but entirely different parallels translational equivalents, which are determined by pragmatics to a greater degree than by semantics.

The analysis is corpus-based. The empirical data has been collected from the Russian National Corpus (RNC) and Språkbanken (the Swedish Language Bank). The RNC is thus far the most comprehensive corpus of Russian. It makes it possible to study the usage of the discourse units in both fictional and journalistic Russian texts starting from the 18th century, and to distinguish obsolete and currently used discourse units. The RNC consists of a collection of corpora, one of which (not very big yet but constantly developing) is the Parallel Corpus, which enables the researcher to thoroughly analyze English translations of the discursive units (in fiction) and vice versa. The search for Swedish translations was done in the parallel corpus Språkbanken (the Swedish Language Bank). Because at present the Russian-Swedish corpus is not adequate to this purpose, we also conducted this search manually. Språkbanken was additionally used to find Swedish examples which use the discursive units of interest to us and which have Russian translations outside this corpus.

Because our goals did not include statistical analysis but merely the confirmation of the basic hypothesis on the discrepancy in the semantic structures of comparable units in different languages, we think that the empirical data is adequate in scope. We have collected some 200 Swedish and 250 English examples. While not enough for a full-fledged statistical analysis, they are entirely sufficient for identifying basic tendencies. All examples were collected between 1 April and 1 June 2014.

The words and constructions under analysis are discussed in groups arranged according to semantic and/or pragmatic proximity.

\section{Imenno vs. kak raz}


To begin with, we will compare two discursive units - imenno and kak raz - in the function of focus sensitive particles in order to determine their specific semantic and pragmatic properties. ${ }^{2}$ As was noted in section 1, in a number of dictionaries such as MAS (I, 661; II 18), BTS (389, 410) imenno and kak raz are understood to be mutual full synonyms. Following Levontina (2004), however, we consider that between these discursive units there are substantial semantic and pragmatic differences, and these will be described in the present section.

\subsection{Semantics}

As a focus particle imenno can be described as follows: 'among a certain number of objects, events, etc. some particular one of them is singled out and focused upon according to the feature that the speaker considers to be decisive, i.e. the most important element of the situation'. Cf. (1).

(1) Nexljudov vspomnil, čto slyšal, kak ètot Šenbok imenno potomu, čto on prožil vse svoe sostojanie i nadelal neoplatnyx dolgov, byl po kakoj-to osobennoj protekcii naznačen opekunom nad sostojaniem starogo bogača, promatyvavšego svoe sostojanie, i teper', očevidno, žil ètoj opekoj. [L. N. Tolstoj. Voskresenie (1899)]

Nekhludoff remembered having heard that this Schonbock, just because, he had spent all he had, had attained by some special influence the post of guardian to a rich old man who was squandering his property - and was now evidently living by this guardianship. [Leo Tolstoy. The Awakening (William E. Smith, 1900)] $]^{3}$

In (1) imenno simply performs a focusing function, singling out one component of the utterance, namely the reason for this particular state of affairs.

The core meaning of kak raz is 'to point out an often random coincidence of two values or parameters'. Unlike imenno, kak raz focuses on the fact that the choice of an object is random or leads to unpredictable results. ${ }^{4} \mathrm{Cf}$. (2).

(2) - Zdravstvuj, Rèd. A ja kak raz tebja išču. - Znaju, - govorju. [A. N. Strugackij, B. N. Strugackij. Piknik na obočine (1971)]

"Hello, Red. I was just coming to see you." "I know." [Arkady Strugatsky, Boris Strugatsky. Roadside Picnic (Antonina W. Bouis, 1977)]

\footnotetext{
${ }^{2} \mathrm{We}$ are interested only in the semantic, pragmatic (and to some extent syntactic) differences between imenno and kak raz and between other discursive units treated in the article. Prosodic differences, the importance of which is discussed on the basis of other discursive units in Kobozeva (2006, 2007), Kobozeva and Zakharov (2004), are a topic for a separate study.

${ }^{3}$ Here and in similar examples the English translation is included for the sake of understanding. Unless otherwise indicated, translations of Russian examples are by Charles Rougle. For a contrastive analysis cf. 2.2, 3.2 and 4.2.

${ }^{4}$ For this reason, imenno is often used in contexts of identification (on contexts of this type cf. in more detail Padučeva 2014). As for kak raz, this discursive unit is more seldom used in such contexts, since the notion of chance coincidence is emphasized in its semantics.
} 
Often what is in the scope of kak raz is an event rather than an object. Cf. (3).

(3) Kak raz togda, kogda Varenuxa, derža v rukax trubku, razdumyval o tom, kuda by emu ešče pozvonit', vošla ta samaja ženščina, čto prinesla i pervuju molniju, i vručila Varenuxe novyj konvertik. [M. A. Bulgakov. Master i Margarita (1929-1940)]

Just as Varenukha, receiver in hand, was pondering where else he might call, the same woman who had brought the first telegram came in and handed Varenukha a new envelope. [Mikhail Bulgakov. Master and Margarita (Richard Pevear and Larissa Volokhonsky, 1979)]

Here two events happen to coincide in time, so that kak raz is more appropriate than imenno (cf. Levontina 2004).

In contexts where the distinctive features are weakened or are not the focus of attention, of course, interchanges are possible. Cf. (4).

(4) Na vsjakij slučaj slonenok rastopyril uši, kak protivouragannye ščity. Kak raz èto i okazalos' samoj bol’šoj ošibkoj. [Alexandr Dorofeev. Ėle-Fantik // «Murzilka», 2003]

To be on the safe side, the little elephant spread its ears like tornado shields. Precisely this proved to be its biggest mistake.

In (4) kak raz singles out an event (the elephant spreading its ears) from among all other possible events and points out a correlation between this event and another event that failed because the first event (spreading its ears) was the wrong thing to do. The first event was a deliberate action, but it was a gamble and led to unpredictable results. Therefore, the use of kak raz in the same context with na vsjakij slučaj/to be on the safe side, meaning 'to take safety precautions in case something happens,' is natural if the story is told from the little elephant's perspective.

It is possible to replace kak raz with imenno, but in that case the interchange would mean that the story is being told from the perspective of a narrator standing outside the inner world of the text.

At the same time, there are contexts in which no such interchange is possible. This applies in particular to the special questions kto imenno? (who, exactly?); čto imenno? (what, exactly?); kogda imenno? (when, exactly?), etc., where *kto kak raz? * čto kak raz? *kogda kak raz? etc. are clearly impossible. ${ }^{5}$ The prohibition against the use of $k a k$ raz is understandable, since the gist of such questions is to focus the interrogative word, and it is not possible to take other values into consideration. The exception among special questions is those introduced by počemu (why) and its synonyms. Cf. (5).

\footnotetext{
${ }^{5}$ According to Levontina 2004, we are dealing with a special reading of imenno in this case, namely "imenno 1 " $\approx$ 'exactly'.
} 
(5) - Pogodi, - skazal Žixar'. - Ty daveča pro osinu govoril, na kotoroj mne, predatelju, povesit'sja. Ty otkuda ètu osinu vzjal? I počemu kak raz osinu, a ne berezu i ne dub, u kotoryx vetki pokrepče budut? [Mixail Uspenskij. Tam, gde nas net (1995)]

"Wait a minute," said Žixar'. "A while ago you were talking about an aspen tree on which to hang me, a traitor. Where did this aspen come from? And why precisely an aspen rather than a birch or an oak, which have stronger branches?"

The reason this is possible is obvious - why-questions presume an underlying comparison of two different values. That is, the question рос̌ети $X$ ? (why X?) can also be construed as počemu $X, a$ ne Y? (why X but not Y).

The difference in the semantics of imenno and kak raz also motivates their syntactic behavior. Unlike kak raz, imenno can function not only as a focus particle but also as a separate utterance. Cf. (5).

(5) - Ne Eleny li Stanislavovny budete synok? - Da. Imenno. (Cf. "Kak raz.) [I. A. Il'f,

E. P. Petrov. Dvenadcat' stul'ev (1927)]

"Not by any chance Elena Stanislavovna's son?" "Right!" [Ilya Ilf, Evgeny Petrov. The

Twelve Chairs (John Richardson, 1961)]

As a separate utterance imenno focuses what was stated in the preceding utterance. Kak raz, on the other hand, always compares two different values, of which at least one must be expressed explicitly. This is confirmed by the corpus data of the RNC. Cf. table 1 .

Table 1. Separate utterances: imenno vs. kak raz

\begin{tabular}{|l|l|l|}
\hline & imenno & kak raz \\
\hline $\begin{array}{l}\text { ending with a full } \\
\text { stop }\end{array}$ & 534 & 0 \\
\hline $\begin{array}{l}\text { ending with an } \\
\text { exclamation point }\end{array}$ & 397 & 0 \\
\hline ending with a dash & 557 & 0 \\
\hline Total & 1488 & 0 \\
\hline
\end{tabular}

As can be seen in table 1, out of a total of more than 10500 contexts in the RNC (without homonym disambiguation) we found 1488 in which imenno is used as a separate utterance. The corresponding results for $k a k r a z$ are 0 contexts as a separate utterance out of a total of more than 24000 without homonym disambiguation. The corpora data indicate that these discursive units 
display non-random differences in syntactic behavior, and they corroborate our hypothesis that these syntactic features have a semantic basis.

When imenno functions as a separate utterance, it displays the variant vot imenno, in which the focusing function is strengthened by the deictic element vot. ${ }^{6} \mathrm{Cf}$. (6).

(6) - Net, ja dumaju, bez šutok, čto dlja togo, čtob uznat' ljubov', nado ošibit'sja i potom popravit'sja, - skazala knjaginja Betsi. - Daže posle braka? - šutlivo skazala žena poslannika. - Nikogda ne pozdno raskajat'sja, - skazal diplomat anglijskuju poslovicu. Vot imenno, - podxvatila Betsi, - nado ošibit'sja i popravit'sja. [L. N. Tolstoj. Anna Karenina (1878)]

"No; I imagine, joking apart, that to know love, one must make mistakes and then correct them," said Princess Betsy. "Even after marriage?" said the ambassador's wife playfully. "It's never too late to mend." The attaché repeated the English proverb. "Just so," Betsy agreed; "one must make mistakes and correct them.” [Leo Tolstoy. Anna Karenina (Constance Garnett, 1911)]

The pragmatics of imenno as a separate utterance is to express agreement with a previously stated or expressed hypothesis or opinion. When used as a separate utterance it often confirms an opinion expressed by the interlocutor, and in such cases the semantic valency normally filled by the focusing element is left unfilled. This unfilled valency is by default filled by an element from the preceding utterance, which in a dialogue is usually the speech of the interlocutor. Thus imenno focuses the central element of the interlocutor's utterance, namely the element of the situation that is critical for it to be understood correctly. ${ }^{7}$

\subsection{Contrastive analysis}

We checked equivalents in bilingual Russian-English (Axmanova and Smirickij 1985, Wheeler et al. 1997, Ermolovič 2011) and Russian-Swedish dictionaries (Birgegård and Sharapova Marklund 2010, Davidsson 1976) and looked for translational equivalents in corpora and works of fiction. In none of these bilingual dictionaries was imenno clearly distinguished as two lexemes - as an independent utterance and as a focus particle. The English near-equivalents of imenno are just, exactly, particular, in particular, indeed, precisely, specifically, obviously, actually, it is... that/who. It is obvious that just, particular, in particular, obviously, and actually

\footnotetext{
${ }^{6}$ The variant vot imenno occurs not only as a separate utterance, but - albeit more seldom - in the position of a focus particle within the utterance.

${ }^{7}$ Analysis shows that imenno as a separate utterance is very similar semantically to to-to $i$ ono. The differences between them will be discussed in section 3 .
} 
can only be translational equivalents of imenno as a focus particle. The equivalents of imenno as a separate utterance are just it, exactly, precisely, indeed, specifically. ${ }^{8} \mathrm{Cf}$. (7).

(7) - Doktor Pil'man, možet byt', Vy skažete svoim zemljakam neskol'ko slov po ètomu povodu? - Čto imenno ix interesuet? [A. N. Strigackij, B. N. Strigackij. Piknik na obočine (1971)]

"Dr Pilman, would you care to say a few words to your fellow townsmen on the subject?"

"What in particular interests you?" 9 [Arkady Strugatsky, Boris Strugatsky. Roadside

Picnic (Antonina W. Bouis, 1977)]

Kak raz has the following translational equivalents: just, exactly, right, right away, surely, precisely, directly, actually. Cf. (8).

(8) Sdajte ob”avlenie Paše. Ona sejčas kak raz edet v nočnuju. Sekretar' sel čitat' peredovuju. [I. A. Il'f, E. P. Petrov. Dvenadcat' stul'ev (1927)]

Give the advertisements to Pasha. He's ${ }^{10}$ just going over there. The editor sat down to read the editorial. [Ilya Ilf, Evgeny Petrov. The Twelve Chairs (John Richardson, 1961)] The Swedish equivalents of imenno are just, exakt, just det, and of kak raz-precis [så]. In translations (besides those considered in dictionaries) we have found the following equivalents: imenno - precis; just precis; förresten; ja, inte sant?; korrekt; jadå. As in English, in Swedish there are various equivalents corresponding to imenno as a focus particle and as an independent utterance - just, förresten can only be translational equivalents of imenno as a focus particle, while just det; ja, inte sant?; jadå are equivalents as a separate utterance. Cf. (9).

(9) Kak èto ni stranno možet pokazat'sja, no Konstantin Levin byl vljublen imenno v dom, v sem'ju, v osobennosti v ženskuju polovinu sem’i Ščerbackix. [L. N. Tolstoj. Anna Karenina (1878)]

Hur underligt det än låter, så hade Konstantin Levin blivit förälskad just i själva hemmet, i hela familjen, särskilt i dess kvinnliga hälft. [Leo Tolstoj. Anna Karenina. (Sigurd Agrell, 1927)]

Strange as it may appear, it was with the household, the family, that Konstantin Levin was in love, especially with the feminine half of the household. [Leo Tolstoy. Anna Karenina (Constance Garnett, 1911)]

\footnotetext{
${ }^{8}$ For reasons of space, in sections 2.2, 3.2 and 4.2 only one illustrative example is provided for each analyzed Russian discursive unit.

${ }^{9}$ Mistranslation - them in the original.

${ }^{10}$ Mistranslation - she in the original.
} 
Ideally, corpus analysis also presumes analysis of the conditions for the use of the relevant elements of the source language - in this case Russian - in reverse translations; that is, in the translation of English and Swedish texts into Russian. Cf. (10).

(10) "Och vid elvatiden på kvällen efter att han blivit skjuten saknades datorn i hans bostad". "Korrekt". [Stieg Larsson. Flickan som lekte med elden (2006)]

- A v odinnadcat' čacov večera, kogda ego zastrelili, noutbuka v kvartire ne okazalos'. Vot imenno. [Stieg Larsson. Devuška, kotoraja igrala s ognem (Inna Streblova, 2009)] "And by 11:00 that night - when the police arrived at his apartment - the computer was gone." "Correct." [Stieg Larsson. The Girl Who Played With Fire (Reg Keland, 2009)] Analysis of even these isolated examples enables us to identify additional correspondences: in (10), for instance, where korrekt is the equivalent of imenno as an independent utterance.

Such words as just, exactly, indeed, actually in English and just, exakt, precis in Swedish can be considered near-synonyms, but they also display different semantic features. These semantic features do not coincide with the semantic features that distinguish imenno from kak raz. This explains the fact that both imenno and kak raz can be translated with the help of the same lexical units.

(11) I imenno tam osobenno živo vspominaetsja Rossija, i imenno derevnja. [L. N. Tolstoj. Anna Karenina (1878)]

(11a) And it's just there that Russia comes back to me most vividly, and especially the country. [Leo Tolstoy. Anna Karenina (Constance Garnett, 1911)]

(11b) Och det är på sådana platser som minnesbilderna från Ryssland, och då just landsbygden, är som starkast. [Leo Tolstoj. Anna Karenina (Ulla Roseen, 2007)] In (11) the first imenno is translated into English (11a) as just, the second as especially. As for the Swedish translations in (11b), the first translational equivalent is the construction det $\ddot{a} r .$. som, the second is just. In other words, there are many ways of expressing the same pragmatic function of imenno in English and Swedish, but there is no exact semantic equivalent on the lexical level. This is also true of kak raz.

We have examined the semantic oppositions and pragmatic similarities and differences between the focusing units imenno and kak raz, and we have also noted the syntactic and pragmatic ability of imenno to function as a separate utterance. This characteristic is semantically motivated and is confirmed by the corpus data of the RNC. Kak raz cannot function as an independent utterance, and this as well is based on semantics and is confirmed by the corpus 
data. For this reason, kak raz and to-to $i$ ono cannot be substituted for each other, and the opposition is therefore irrelevant.

If kak raz is a near-synonym of imenno as a focus particle, imenno as an independent utterance has other near-synonyms such as to-to $i$ ono, to-to i est', to-to i delo, v tom-to i delo, toto že, etc. In turn here we will examine to-to i ono, to-to $i$ est', and to-to i delo, and section 3 will discuss the opposition between imenno and to-to $i$ ono as separate utterances.

\section{Imenno vs. to-to $i$ ono}

\subsection{Semantics, pragmatics}

MAS (I, 661; IV, 391) interprets imenno in the relevant meaning as an "affirmative word", and to-to $i$ ono as a unit that is "commonly used for affirmation or emphasis of something said". From these interpretations it is difficult to understand just what constitutes the semantic and pragmatic differences between these discursive units. To-to $i$ ono is described in general and more fully in phraseological dictionaries such as Molotkov (1967) and Lubensky (2013). For more detail see section 4.1 .

To-to $i$ ono as a separate utterance can be defined as: 'what the speaker determines to be the most important element in the interlocutor's utterance, that which is crucial to an adequate understanding of a given situation.' Cf. (12).

(12) - Skažite, tovarišč Gavrilov, odnoj li perevozkoj kontrabandy delo ograničivaetsja?

Kombat otvetil ugrjumo: - Vot to-to i ono-to! [N. A. Ostrovskij. Kak zakaljalas' stal' (č. 2) (1930-1934)]

"Probably there's something more serious than smuggling going on. What do you say, Comrade Gavrilov?" “That's just the trouble,” the Battalion Commander replied gloomily. [Nikolai Ostrovsky. How the Steel was Tempered (pt 2) (R. Prokofieva, 1952)] In (12) to-to $i$ ono serves to single out the most important element in the utterance of the interlocutor from the perspective of the speaker, namely "there's something more serious than smuggling going on."

In cases where the main element of the situation coincides with the element in the interlocutor's utterance that the speaker singles out as most important, imenno and to-to $i$ ono are interchangeable, since the subtle differences between them are neutralized. Cf. (13). 
(13) - Zapomnite, mamaša, - buržua. Žujut oni nas, žujut i vsasyvajut. - Bogatye, značit? - sprosila mat'. - Vot imenno! V ètom ix nesčastie. [Maksim Gor'kij. Mat' (1906)]

"Remember that word, dear granny - bourgeois! Brr! How they chew us and grind us and suck the life out of us!" "The rich, you mean?" "Yes, the rich. And that's their misfortune." [Maxime Gorky. Mother (D. J. Hogarth, 1921)]

Otherwise such an interchange is either undesirable or causes a shift of accent. Cf. (14).

(14) - Ponjatno. Nado bylo takie dela drugim poručat'. Ėto tebe ne na mašinke stukat'. Net, ja sam dolžen byl. - A esli by Bati sidel? - Nu, esli by sidel. Vot to-to i ono! [Mixail Gigolašvili. Čertovo koleso (2007)]

"I see. These things should have been entrusted to someone else. It's not something you can just bat out on a typewriter." "No, I had to do it myself." "And if Bati had been in jail?" "Well, if he'd been in jail. That's just the thing!"

In (14) to-to $i$ ono singles out only the main element in the utterance of the interlocutor. Since that sentence is in the subjunctive, to-to $i$ ono here refers to a hypothetic situation. In such cases substitution with imenno is undesirable.

Another constraint that makes the interchange undesirable is constructional in nature. To-to $i$ ono can combine with the clitic -to, which is not the case with imenno. Cf. (15).

(15) - A ty ego klass vedeš' teper'... U nego vse otličniki oni byli... ran'še, - on podmignul mne, - a teper'? U tebja?.. - Kakie že oni otličniki, kogda èlementarnyx veščej?.. - Vot to-to i ono-to... - I on zasmejalsja. [Bulat Okudžava. Noven'kij kak s igoločki (1962)]

"And you are teaching his class now... With him they were all top students... earlier," he winked at me, "but now? With you?" "What sort of top students are they, when it's just a question of elementary things?..." "That's just what I mean...” And he laughed.

The ability to combine with the clitic -to is evidently connected with the polemical element contained in the pragmatic potential of to-to $i$ ono. In contrast to imenno, the basic pragmatic feature of to-to $i$ ono is argumentativeness, which presumes disagreement - both with one of the participants in the situation and with the hypothetical supporters of an opinion that does not coincide with that of the speaker. Cf. (16) and (17).

(16) Otvet: Gospodi, čego tol'ko ne byvaet! Ee podmenili vo dvorce, a ego v roddome. Vopros: V kakom dvorce? Otvet: A počemy vy ne sprašivaete, v kakom roddome? To-to $i$ 
ono! Vse xotjat uznat', kak podmenivajut vo dvorcax [...]. I nikomu ne interesno pro rajonnuju bol'nicu [...]. [Mixail Šiškin. Venerin volos (2004) // «Znamja», 2005]

Answer: Lord, the things that happen! Her they switched in the palace, and him in the birthing home. Question: in which palace? Answer: Why don't you ask in which birthing home? That's the whole point! Everyone wants to know how babies get switched in the palaces ... And nobody cares about a district hospital [...].

(17) - Tam ros reliktovyj granatovyj les, - govorit Abbas. - Ty videl kogda-nibud' dikij granat, kotoromu tri veka v korne? Vot to-to i ono. [Aleksandr Iličevskij. Pers (2009)] "There used to be an old-growth pomegranate forest there," says Abbas. "Have you ever seen a three-hundred-year-old wild pomegranate? That's the whole problem."

The polemical aspect is particularly obvious in examples where to-to $i$ ono is a reaction to a rhetorical question, as in (16) and (17). In these cases substituting imenno is undesirable. When substitution is possible, the contexts are still not identical pragmatically, since imenno has a different semantic prosody. Here to-to $i$ ono is always potentially argumentative.

We have also checked the frequency occurrences in the RNC for imenno and to-to $i$ ono as an independent utterance both with vot and without. Cf. table 2.

Table 2. Separate utterance: imenno vs. to-to $i$ ono

\begin{tabular}{|l|l|l|l|l|}
\hline & \multicolumn{2}{|l|}{ imenno } & \multicolumn{2}{l|}{ to-to $i$ ono } \\
\hline & imenno & $\begin{array}{l}\text { vot } \\
\text { imenno }\end{array}$ & $\begin{array}{l}\text { to-to } i \\
\text { ono }\end{array}$ & $\begin{array}{l}\text { vot to-to } i \\
\text { ono }\end{array}$ \\
\hline $\begin{array}{l}\text { ending with a full } \\
\text { stop }\end{array}$ & 228 & 306 & 59 & 36 \\
\hline $\begin{array}{l}\text { ending with an } \\
\text { exclamation point }\end{array}$ & 167 & 230 & 60 & 24 \\
\hline ending with a dash & 242 & 315 & 25 & 21 \\
\hline Total & 637 & 851 & 144 & 81 \\
\hline
\end{tabular}

In the RNC we found 1488 examples with imenno (of a total of more than 10500 without preliminary homonym disambiguation) and 225 with to-to $i$ ono (out of a total of 316 ). Evidently this is because the construction to-to $i$ ono has additional meanings that demand more specific contexts.

\subsection{Contrastive analysis}


According to Lubensky (2013: 637-238) the English equivalents of to-to $i$ ono are that's just it /the thing/ the point); that's the whole point; (and) that's the problem/ the trouble; you've put your finger on it; my point exactly; that's just my point; the thing is...; the (whole) point is...; my point is...; the problem/the trouble is.... The Swedish equivalents considered in Birgegård and Sharapova Markund (2010: 711) are just [så är] det, precis. In addition, we have found the following equivalents in works of fiction: jag vill mena det; jo; det är just det; jo, jo... det är just det, så är det med den saken, exakt.

The Swedish equivalents precis, just det and exakt are possible only in contexts where the polemical element is neutralized, and they are therefore used to translate imenno and to-to $i$ ono. The same applies to English equivalents such as that's just it/the thing/the point; that's the whole point. Other equivalents are required to translate to-to $i$ ono in contexts where the polemical element is focused.

\section{To-to i ono vs. to-to $i$ est' and to-to i delo}

Molotkov (1967: 479) describes the discursive units to-to $i$ ono and to-to i est' as synonyms, and these units are interpreted in two verbatim entries with mutual references.

TO-TO • < VOT > TO-TO I EST' Coll. Expression, usually didactic or reproachful in nature, acknowledging the correctness of what has been said. Cf. $<$ vot $>$ to-to i ono. $<$ VOT > TO-TO I ONO Coll. Expression, usually didactic or reproachful in nature, acknowledging the correctness of what has been said. Cf. $<$ vot $>$ to-to i est' ${ }^{11}$

Lubensky (2013: 637-638) defines the two units in one entry as synonymous and identical in function:

(VOT) TO-TO I ONO < ONO-TO>; (VOT) TO-TO (ONO) I EST' all coll [Interj; used as indep. sent or main clause in a complex sent (usu. foll. by a что-clause); these forms only; fixed WO] this/that is the important factor, the essential thing (used to emphasize that what has just been said or is about to be said is the central issue, the most important aspect of the matter in question): that's just it <the thing, the point $>$; that's the whole point; [lim.] (and) that's the problem <the trouble>; you've put your finger on it; my point exactly; that's just my point; [when foll. by a что-clause] the thing is...; the (whole) point is...; my point is...; [lim.] the problem $<$ the trouble $>$ is...

\footnotetext{
${ }^{11}$ To facilitate understanding, the entry is translated into English
} 
Lubensky considers these two constructions both in the function of an independent sentence and in the function of a main clause in a complex sentence followed by a čto-clause. In the present analysis we consider the constructions only as independent sentences.

To-to $i$ delo it is not addressed in any of the dictionaries that we have checked. Our analysis of the corpus data indicates that there are significant non-semantic differences between the three units.

\subsection{Semantics, pragmatics}

As we are going to show using corpus evidence, to-to $i$ est' and to-to $i$ delo are hardly ever used in present-day Russian, while to-to $i$ ono occurs frequently. The semantic and pragmatic characteristics of these first two constructions, therefore, can only be described in general terms. Context analysis shows that between to-to i ono, on the one hand, and to-to i est' and to-to $i$ delo, on the other, there is a clear semantic and pragmatic similarity. Cf. (18) and (19).

(18) Oleg edva sderžival sebja i izbegal smotret' na Staxoviča. - K-kak tvoe mnenie, Sereža? - Lučše by napast', - skazal Serežka, smutivšis'. - To-to i est' .. [A. A. Fadeev. Molodaja gvardija (1943-1951)]

Oleg could hardly restrain himself and avoided looking at Stakhovich. "W-what do you think, Sergei?" "I think we'd better make the attack," Sergei said in some confusion. "That's it, then." [Alexander Fadeev. The Young Guard (Violet Dutt, 1958)] (19) - Imja, sudar', imja! Ėto vsego nužnee v našej knižnoj kommercii. - Da gde ž mne prikažeš' ego vzjat'? - Vot to-to i delo! [M. N. Zagoskin. Moskva i moskviči (1842-1850)]

“A name, sir, a name! That's what's needed most of all in our book trade." "But where am I supposed to find it?" "That's the whole problem!"

In (18) and (19) the three constructions are interchangeable, at least from the perspective of present-day usage.

The construction to-to $i$ ono and the constructions to-to $i$ est' and to-to $i$ delo all have a polemical potential. Cf. (20) and (21).

(20) - Interesno, čemu ix tam v gorodax učat? - Izvestno čemu, - soobrazil Čonkin. - Salo derevenskoe žrat'. - To-to i est', - soglasilas' Njura. [Vladimir Vojnovič. Žizn' i neobyčajnye priključenija soldata Ivana Čonkina (1969-1975)] 
"I wonder what they teach them there in the city." "That's easy," announced Chonkin. "To live off the fat of the countryside." "That's for sure," agreed Nyura. [Vladimir Voinovich.

The Life and Extraordinary Adventures of Private Ivan Chonkin (Richard Lourie, 1977)] In (20) Njura expresses agreement with Čonkin that town-dwellers learn only one thing about the countryside - how to live off the fat of the countryside.

(21) A otkeda, skaži, iz zaviruxi burannoj krov'? Veter ved' èto, vozdux, snegovaja pyl'. A to-to $i$ est', kuma, ne veter èto buran, a razvedenka-oborotenka detenyša-ved'menočka svoego poterjala, iščet v pole, plačet, ne možet najtit'. [B. L. Pasternak. Doktor Živago $(1945-1955)]$

And how is it, tell me, that blood can come from a stormy whirl? Isn't it just wind, air, snowy powder? But the fact is, my pet, that the storm is not wind, it's a changeling shewerewolf that's lost her young one, and searches for him in the field, and weeps because she can't find him. [Boris Pasternak. Doctor Zhivago (Richard Pevear and Larissa Volokhonsky, 2010)]

In (21) to-to i est' is not only polemical but also expresses disagreement with the question asked in the speaker's preceding sentence. From the viewpoint of present-day usage it is difficult to judge whether replacing to-to $i$ i est' and to-to delo with to-to $i$ ono would add any extra element to the utterance.

In order to find possible usage differences between to-to $i$ ono, to-to $i$ est' and to-to $i$ delo, we analyzed all contexts from the RNC containing these constructions. The search yielded 393 contexts with to-to $i$ ono, 449 with to-to i est', and 41 with to-to i delo. The frequency of occurrence is shown in table 3.

Table 3. To-to i ono, to-to i est'and to-to i delo: frequency of occurrence in the RNC

\begin{tabular}{|l|l|l|l|}
\hline number of occurrences & to-to $i$ ono & to-to $i$ est' & to-to i delo \\
\hline Total & 393 & 449 & 41 \\
\hline from 1970s & 259 & 4 & 3 \\
\hline $1960 \mathrm{~s}$ & 33 & 1 & 1 \\
\hline $1950 \mathrm{~s}$ & 24 & 13 & 1 \\
\hline $1940 \mathrm{~s}$ & 9 & 11 & 0 \\
\hline $1930 \mathrm{~s}$ & 19 & 25 & 0 \\
\hline $1920 \mathrm{~s}$ & 20 & 17 & 8 \\
\hline $1910 \mathrm{~s}$ & 11 & 10 & 2 \\
\hline
\end{tabular}




\begin{tabular}{|l|l|l|l|}
\hline $1900 \mathrm{~s}$ & 11 & 26 & 3 \\
\hline XIX century & 6 & 342 & 23 \\
\hline
\end{tabular}

The constructions to-to i est' and to-to i delo are not used in present-day Russian. They were frequent in the nineteenth century, however, and therefore should be labeled as archaic. To-to $i$ ono, in contrast, is frequent in modern usage but was practically not used in the nineteenth century. From the 1920s through the 1940s to-to i ono and to-to i est' were equally frequent. This balance was disturbed in the 1950s, leading to the disappearance of to-to i est'. As for to-to $i$ delo, it is approximately ten times less frequent in the RNC in comparison with to-to $i$ ono and to-to $i$ est' and was practically not used after the 1920s. To-to i ono-to occurs in contexts throughout the whole period, beginning in the nineteenth century.

It should also be pointed out that because the RNC is relatively small (the main corpus includes about 200 million running words), the results can be considered only preliminary and must be verified on the basis of larger corpora.

We have also observed some differences in combinatorics. To-to i ono combines easily with -to, while combinations of to-to i est' and to-to i delo with -to occur very seldom. ${ }^{12}$ We have found 54 contexts with to-to $i$ ono-to, 2 contexts with to-to i est'-to and no examples with to-to $i$ delo-to; cf. (22) and (23).

(22) Kazalos’ by, čto ešče čeloveku nužno? No čelovek, osobenno čelovek tvorčeskij, kak izvestno, nikogda ne ostanavlivaetsja na dostignutom. Postavil odin unitaz, xočetsja postavit' vtoroj, a kuda? Vot to-to i ono-to... [Vladimir Vojnovič. Ivan'kiada, ili Rasskaz o vselenii pisatelja Vojnoviča v novuju kvartiru (1976)]

It would seem a man could want no more. But, as is well-known, a man, especially a creative man, never rests on his accomplishments. He puts in one toilet; then he wants to put in another. But where? Ah, that's the problem! [Vladimir Voinovich. The Ivankiad (David Lapeza, 1976)]

(23) - Čtoby ètu knigu pravil'no opredelit', ee vsju pročitat' nužno, - obratilsja on nakonec k Lapinu tonom upreka. - Ėto dolgo, - skazal doktor vinovatym golosom [...]. - To-to $i$ est'-to! [F. D. Krjukov. Obysk (1906-1915) // «Sovetskaja Rossija», 1990]

\footnotetext{
${ }^{12}$ A search in Google Books yielded 3 examples with to-to i est'-to and 3 examples with to-to i delo-to.
} 
"To classify this book correctly it will be necessary to read it in its entirety," he finally addressed Lapin in a reproachful tone. "That will take a long time," said the doctor in a guilty voice. "Precisely!"

To-to $i$ est' combines more often with vocatives than to-to $i$ ono: a search in the RNC gave 43 contexts with to-to $i$ est' and 12 with to-to $i$ ono. Cf. (24).

(24) - Pojdem-ka. Posmotriš', kak ja živu i rabotaju. - Večerom spektakl', - vozrazil Lik, - i zavtra ja uezžaju! - To-to i ono, milyj, to-to i ono. Xvataj! Pol'zujsja! Drugogo šansa nikogda ne budet. [V. V. Nabokov. Lik (1938)]

"Come on, let's go. You'll see how I live and work." "I have a performance tonight, "Lik objected, "and I'm leaving tomorrow." "That's just the point, my friend, that's just the point. Seize the opportunity! Take advantage of it! There will never be another chance." [Vladimir Nabokov. Lik (Vladimir Nabokov, 1966)]

Most of the contexts with to-to $i$ est' are from the nineteenth century. To explain this phenomenon, we would at a minimum need to have information on the statistical distribution of vocatives in the speech of nineteenth-century literary characters as compared with present-day literature.

4.2 Contrastive analysis

Both Lubensky (2013) and Birgegård and Sharapova Markund (2010) consider English and Swedish equivalents of to-to $i$ est' together with to-to $i$ ono. Cf. 3.2. As for to-to $i$ delo, we have found two examples in the parallel corpus with to-to i est' in the RNC. Cf. (25).

(25) - Da začem že ty tak odelsja? Ty smotriš’ kakim-to ploxim gorodskim meščaninom ... ili raznoščikom... ili otstavnym dvorovym. Otčego ètot kaftan, a ne poddevka ili prosto krest'janskij armjak? - To-to i est', - načal Neždanov, kotoryj v svoem kostjume dejstvitel'no smaxival na melkogo prasola iz meščan [...]. [I. S. Turgenev. Nov' (1877)]

"But why did you get yourself up like this? You look like some sort of shopkeeper, or pedlar, or a retired servant. Why this long coat? Why not simply like a peasant?" "Why?" Nejdanov began. He certainly did look like some sort of fishmonger in that garb [...]. [Ivan Turgenev. Virgin Soil (Rochelle S. Townsend, 1929)]

As often happens in translations of literary works, in both contexts the pragmatic thrust of the dialogue is captured, but there are no lexical equivalents of to-to i est'. The Swedish equivalents behave similarly. Cf. (26). 
(26) - Oni otvergajut spravedlivost' sobstvennosti, kapitala, nasledstvennosti, a ja, ne otricaja ètogo glavnogo stimula [...], xoču tol'ko regulirovat' trud. - To-to i est', ty vzjal čužuju mysl', otrezal ot nee vse, čto sostavljaet ee silu, i xočeš' uverit', čto èto čto-to novoe, - skazal Nikolaj, [...]. [L. N. Tolstoj. Anna Karenina (1878)]

”De förkastar rättmätigheten i ägandet, kapitalet, arvet, medan jag inte alls bestrider sådana viktiga stimuli $[\ldots]$ utan bara vill reglera arbetet." "Det är just det jag menar, du har tagit någon annans tanke, skurit bort allting som ger den styrka och sedan envisas du med att påstå att du har kommit på något nytt”, sa Nikolaj [...]. [Lev Tolstoj. Anna Karenina (Ulla Roseen, 2007)]

"They deny the justice of property, of capital, of inheritance, while I do not deny this chief stimulus." [...] "All I want is to regulate labor." "Which means, you've borrowed an idea, stripped it of all that gave it its force, and want to make believe that it's something new," said Nikolay, [...]. [Leo Tolstoy. Anna Karenina (Constance Garnett, 1911)]

In the Swedish translation of this passage, the construction det är just det is an adequate pragmatic equivalent of to-to i est'. In the dictionaries we consulted and in the parallel corpus there were no equivalents of the construction to-to $i$ delo.

\section{Conclusion}

Our analysis shows that in the discursive examples in Russian considered here, synonymy is not as complete as it appears at first glance. Using examples of synonymous particles and phrasemes, we have demonstrated that seemingly fully synonymous particles and constructions such as to-to $i$ ono, to-to $i$ est' and to-to $i$ delo or imenno and kak raz differ with respect to their syntactic use and certain semantic and pragmatic features, as well as from the perspective of diachrony, style, and frequency.

Our work with the corpus indicates that there are almost no cases in which the use of one near-synonym is correct and another entirely impossible. Interchanges are practically always permissible, albeit with different frequency and different degrees of cognitive entrenchment. Sometimes substitutions produce slight shifts that are always apparent to a sensitive native speaker. The following assumptions were advanced as working hypotheses of the study: a) differences between near-synonyms are determined not only by semantics, but can also be motivated by pragmatics and usage; 
b) syntactic differences between the synonyms under consideration are motivated by distinctions in their semantics;

c) different languages, when they do not have good semantic equivalents, solve the problem on the level of the utterance, where they use not systematic equivalents but entirely different parallels - translational equivalents, which are determined more by pragmatics than by semantics.

The corpus data have confirmed all three hypotheses. As for the first of these, the differences between imenno and kak raz have primarily to do with semantics. If imenno as a focus particle singles out the element of the utterance that is within its sphere of influence, the semantics of kak raz presumes the explicit or implicit comparison of two values. All other differences - pragmatic, syntactic, and usual - derive from this basic semantic distinction. The differences between imenno and to-to $i$ ono depend in equal measure upon semantics and pragmatics. From the semantic point of view, imenno as an independent utterance underscores what the speaker regards as the main element of the situation, whereas to-to $i$ ono focuses the main element of the preceding utterance. This binds to-to $i$ ono more closely to the verbal form. In most contexts, of course, this difference is neutralized. The principal pragmatic difference between to-to $i$ ono and imenno is that to-to $i$ ono contains a polemical element, which in part explains the semantic difference noted above. The differences between to-to i ono, to-to $i$ est' and to-to $i$ delo are based solely on usage. Of the three constructions, only to-to $i$ ono is typical of modern usage, while to-to i est' and to-to i delo are perceived as archaic, which is indeed confirmed by the corpus data. The data also confirm that to-to $i$ delo is used much more seldom than to-to i est' and can be considered practically obsolete.

The second hypothesis on the semantic motivation of syntactic differences has been confirmed on the basis of the opposition between imenno and kak raz. The fact that imenno can function both as a focus particle and as an independent utterance, whereas kak raz can only serve as a focus particle, derives from the semantic differences between these units discussed in section 2.1.

The third hypothesis is also confirmed. The analysis (see sections 2.2, 3.2 and 4.2) has shown that in order to find a functional equivalent that can be adequately used in the translation of a given context it is not at all necessary to have an equivalent in the language system.

\section{Acknowledgements}


This paper is based on work supported by the RFFI under Grant 13-06-00403. Thanks also go to Pierre-Yves Modicom (Université Paris-Sorbonne), who read a draft version of the present article, for an interesting discussion of theoretical issues raised by us, and to the anonymous reviewers for a number of valuable comments that we have attempted to take into account.

\section{Literature}

Axmanova, Ol'ga S. and Aleksandr I. Smirnickij. 1985. Russko-anglijskij slovar'. [RussianEnglish Dictionary] Moskva: Russkij jazyk.

Baranov, Anatolij N., Vladimir A. Plungjan and Ekaterina V. Raxilina. 1993. Putevoditel' po diskursivnym slovam russkogo jazyka. [Guide to Russian discursive words] Moskva: Pomovski \& Partner.

Birgegård, Ulla and Elisabeth Sharapova Marklund (eds.). 2010. Norstedts ryska ordbok: rysksvensk, svensk-rysk. [Norstedt's Russian dictionary: Russian-Swedish, Swedish-Russian] Stockholm: Norstedts akademiska förlag.

BTS - Bol'šoj tolkovyj slovar' russkogo jazyka [Comprehensive explanatory dictionary of Russian], ed. Sergej A. Kuznecov. Sankt-Peterburg.

Davidsson, Karin (ed.). 1976. Russko-švedskij slovar'. [Russian-Swedish dictionary] Moskva: Russkij jazyk.

Dobrovol'skij, Dmitrij O. and Irina B. Levontina. 2012. O sinonimii fokusirujuščix častic (na materiale nemeckogo i russkogo jazykov) [Synonymous focus particles in German and Russian]. In Computational linguistics and intellectual technologies. Papers from the annual international conference “Dialogue 2012”. Issue 11 (18), 2012. Volume 1, 138-149. Moskva: RGGU.

Dobrovol'skij, Dmitrij O. and Irina B. Levontina. 2014. Timiologičeskij komponent v semantike diskursivnyx slov. [The timiological component in the semantics of discursive words] In Trudy Instituta russkogo jazyka RAN II, ed. Aleksej D. Šmelev, 334-343. Moskva: Institut russkogo jazyka.

Dobrovol'skij, Dmitrij and Artem Šarandin. 2013. Die Fokuspartikel EBEN und ihre Quasisynonyme in deutsch-russischer lexikographischer Perspektive. In Germanistische Linguistik, 221-222, eds. Eva Breindl and Annette Klosa, 19-57. Hidesheim, Zürich, New York: Georg Olms Verlag.

Ermolovič, Dmitrij I. 2011. Anglo-russkij i russko-anglijskij slovar' [English-Russian and Russian-English dictionary]. Moskva: AST, Astrel', Xarvest. 
Fischer, Kerstin. 2000. From cognitive semantics to lexical pragmatics: the functional polysemy of discourse particles. Berlin: Mouton de Gruyter.

Kiseleva, Ksenija L. and Denis Paillard (eds.). 1998. Diskursivnyje slova russkogo jazyka: opyt kontekstno-semantičeskogo opisanija. [Russian discursive words: an attempt at a contextsemantic description] Moskva: Metatekst.

Kiseleva, Ksenija L. and Denis Paillard (eds.). 2003. Diskursivnyje slova russkogo jazyka: kontekstnoe var'irovanie i semantičeskoe edinstvo. [Russian discursive words: contextual variation and semantic invariance] Moskva: Azbukovnik.

Kobozeva, Irina M. 2006. Opisanie označajuščego diskursivnyx slov v slovare: nerealizovannye vozmožnosti. [Describing the signifier of discursive words in the dictionary: unrealized possibilities] In Vestnik $M G U$. Serija 9, 2. Filologija.

Kobozeva, Irina M. 2007. Polisemija diskursivnyx slov i vozmožnosti ee razrešenija v kontekste predloženija (na primere slova vot). [Ambiguity of discourse markers - can it be resolved in clausal context? (the case of vot).] In Computational linguistics and intellectual technologies. Papers from the annual international conference "Dialogue 2007”. Vypusk 6 (13), 250-255. Moskva: RGGU.

Kobozeva, Irina M. and Leonid M. Zakharov 2004. Types of information for the multimedia dictionary of Russian discourse markers. In Proceedings of the 9th international conference “Speech and computer”. St-Petersburg: St-Petersburg University.

Levontina, Irina B. 2004. Imenno 2, kak raz 1. In Novyj ob "jasnitel'nyj slovar' sinonimov russkogo jazyka, ed. Jurij D. Apresjan. Izd. 2 ispr. i dop. Moskva; Wien: Jazyki slavjanskoj kul'tury, Wiener Slawistischer Almanach.

Lubensky, Sophia. 2013. Russian-English dictionary of idioms. New Haven: Yale University Press.

MAS - Malyj akademičeskij slovar' = Slovar' russkogo jazyka v uetyrex tomax. [Dictionary of Russian in four volumes] 1985-1988. 3-e, stereotip. izd. Moskva: Russkij jazyk. Molotkov, Aleksandr I. (ed.). 1967. Fraseologičeskij slovar’ russkogo jazyka. [Phraseogical dictionary of Russian] Moskva: Sovetskaja ėnciklopedija.

Padučeva, Elena V. 2014. Nestandartnye otricanija v russkom jazyke: vnešnee, smeščennoe, global'noe, radikal'noe. [Nonstandard negations in Russian: external, shifted, global, radical] In Voprosy jazykoznanija, 5: 3-23. 
Paillard, Denis. 1998a. Kak raz ili Mirom pravit slučaj. [Kak raz, or The world is ruled by chance] In Diskursivnyje slova russkogo jazyka: opyt kontekstno-semantičeskogo opisanija, eds. Ksenija Kiseleva and Denis Paillard, 278-284. Moskva: Metatekst.

Paillard, Denis. 1998b. Imenno ili Kak nazyvat' vešči svoimi imenami. [Imenno, or How to call things by their names.]. In Diskursivnyje slova russkogo jazyka: opyt kontekstno-semantičeskogo opisanija, eds. Ksenija Kiseleva and Denis Paillard, 285-293. Moskva: Metatekst.

Paukkeri, Pirkko. 2006. Recipient v russkom razgovore: o raspredelenii funkcij meždu otvetami da, nu $i$ tak. [The recipient in Russian conversation: on the distribution of functions between the answers $d a, n u$, and tak] Helsinki: Helsinki Univ.

Romero-Trillo, Jesus. 2009. Discourse markers. In Concise encylopedia of pragmatics, ed. J. Mey. 2nd ed., 191-194. Amsterdam: John Benjamins.

Šaronov Igor’ A. 2009. Kommunikativy i metody ix opisanija. [Communicative units and methods of their description] In Computational linguistics and intellectual technologies. Papers from the annual international conference "Dialogue 2009”. Vypusk 8 (15), 543-548. Moskva: RGGU.

Sorjonen, Marja-Leena. 2001. Responding in conversation. A study of response particles in Finnish. Philadelphia, PA: John Benjamins.

Travis, Catherine E. 2005. Discourse markers in Colombian Spanish: a study in polysemy. Berlin: Mouton de Gruyter.

Wheeler, Marcus, Boris Unbegaun and Paul Falla (eds.). 1997. The Oxford Russian dictionary (revised and updated Colin Howlett). Oxford: Oxford University Press. 